\title{
PENILAIAN BAHAN AJAR BAHASA MADURA TINGKAT SEKOLAH MENENGAH ATAS (SMA)
}

\author{
M. Khoiri' ${ }^{1}$, Kusyairi ${ }^{2}$ \\ 1Universitas Madura Pamekasan, khoiri83@unira.ac.id \\ 2Universitas Madura Pamekasan, kusyairi@unira.ac.ic
}

\begin{abstract}
Abstrak
Tujuan penelitian ini adalah untuk mengetahui informasi dan mendeskripsikan tentang kualitas bahan ajar bahasa Madura baik dari segi isi, penyajian, maupun bahasa. Adapun jenis penelitian ini adalah penelitian evaluasi yakni dengan melakukan kajian dokumen kurikulum bahasa Madura tingkat SMA (silabus) serta instrumen-instrumen penelitian yang diberikan kepada siswa dan ahli materi. Hasil penelitian menunjukkan bahwa respon siswa tentang bahan ajar bahasa Madura tingkat SMA termasuk kategori valid dan dapat digunakan tetapi perlu revisi kecil, yakni dengan nilai 70.64. Sedangkan hasil validasi ahli materi menyatakan bahwa bahan ajar bahasa Madura dalam kategori kurang valid dan dapat digunakan tetapi perlu revisi, yakni dengan nilai 66,88.
\end{abstract}

Kata kunci: penilaian, bahan ajar, bahasa Madura

\author{
M. Khoiri' ${ }^{1}$, Kusyairi ${ }^{2}$ \\ 1Universitas Madura Pamekasan, khoiri83@unira.ac.id \\ 2Universitas Madura Pamekasan, kusyairi@unira.ac.ic
}

\begin{abstract}
The purpose of this study was to find out information and describe the quality of Madurese language teaching materials both in terms of content, presentation, and language. The type of this research is development research, namely by conducting a high school level Madura curriculum curriculum (syllabus) study as well as research instruments given to students and material experts who subsequently produce teaching materials. The results of the study showed that the students' response to the Madura language teaching material at the high school level was in the valid category and could be used but needed a small revision, with a value of 70.64. Whereas the results of the material expert validation state that Madurese language teaching materials in the category are less valid and can be used but need revision, with a value of 66.88 .
\end{abstract}

Keywords: assessment, teaching materials, Madurese language 


\section{A. PENDAhUluan}

Mata pelajaran Bahasa Madura sebagai salah satu mata pelajaran muatan lokal harus terus dikembangkan dan diperbaharui dalam penyajiannya. Hal ini harus dilakukan dalam rangka memudahkan setiap peserta didik memahami materinya. Oleh karena itu, para ahli harus melalukan pembaharuan untuk mencari desain dan sistematika ajar yang lebih fleksibel, yakni melalui ajar bahasa Madura di tingkatan Sekolah Menengah Atas (SMA) sehingga dapat tersusun secara komunikatif, interaktif, serta berorientasi pada kebutuhan peserta didik. Selain itu, untuk peningkatan mutu ajar, guru harus mempersiapkan rancangan materi agar peserta didik dapat dengan mudah memahami, mencerna, dan bahkan merasakan sedang berinteraksi dengan pendidiknya. Sehingga akhirnya peserta didik bisa dibimbing secara khusus dalam mempelajari materi secara mandiri dengan lebih efektif dan efisien.

Selain itu, IPTEKS saat ini berkembang pesat selaras dengan dinamika sosial masyarakat, begitu pula materi dalam bahan ajar dituntut juga untuk dinamis. Oleh karena itu diperlukan serangkaian kegiatan yang berkelanjutan untuk melakukan pengkajian/penelaahan terhadap materi bahan ajar agar lebih baik. Hal ini dimaksudkan untuk melihat kualitas bahan ajar sebagai sumber belajar siswa serta untuk menjaga kualitas pembelajarannya, maka telaah bahan ajar perlu dilakukan dan untuk ini pengusul belum pernah menemukan artikel penelaahan bahan ajar yang dimaksud. \begin{tabular}{lccc}
\multicolumn{2}{c}{ Pengembangan } & bahan ajar \\
bahasa & Madura & merupakan \\
serangkaian & kegiatan & pengkajian
\end{tabular} terhadap yang telah digunakan apakah materi-materi yang terdapat dalam bahan masih relevan dengan kondisi saat ini, apakah diperlukan perubahan karena dianggap materi sudah tidak sesuai lagi. Pengembangan bahan ajar dalam penelitian ini melibatkan guru pengampu, peserta didik, dan pakar atau ahli materi.

Adapun penerapan pendekatan kontekstual dalam peneltian ini merupakan suatu konsep belajar dimana guru menghadirkan situasi dunia nyata ke dalam kelas dan mendorong siswa membuat hubungan antara pengetahuan yang dimilikinya dengan penerapannya dalam kehidupan mereka sebagai anggota keluarga dan masyarakat.

Hasil pembelajaran diharapkan lebih bermakna bagi siswa untuk memecahkan persoalan, berpikir kritis dan melaksanakan observasi serta menarik kesimpulan dalam kehidupan jangka panjangnya. Dalam konteks itu, siswa perlu mengerti apa makna belajar, apa manfaatnya, dalam status apa mereka dan bagaimana mencapainya.

Selain mendapatkan informasi tentang "kekurangan" bahan ajar juga dimanfaatkan untuk merevisi bahan ajar tersebut. Dengan demikian, tujuan pokok dari pengembangan bahan ajar bahasa Madura adalah berusaha meningkatkan kreativitas dan minat guru dan siswa dengan memperhatikan komponenkomponen pendekatan kontekstual, sehingga kegiatan belajar dan mengajar lebih menyenangkan serta dalam rangka mencapai tuntutan kompetensi dan meningkatkan hasil 
belajar siswa.

Melihat sekilas dari materi bahan ajar bahasa Madura menurut pengusul perlu diadakan telaah dan pengembangan seca ralebih mendalam. Selain itu masih banyak materi yang perlu pembaharuan serta sistempenyajian yang perlu ditinjau kembali.

Oleh karena itu, dalam penelitian ini dikembangkan bahan ajar bahasa Madura dengan pendekatan kontekstual dan diharapkan ajar ini dapat memberikan kemudahan dan kontribusi pengetahuan dan pengayaan bahan ajar bahasa Madura untuk guru dan siswa pada tingkat Sekolah Menengah Atas (SMA).

\section{B. METODE}

Penelitian ini menggunakan metode penelitian dan pengembangan (Research and Development). Sugiyono (2011:297) menyebutkan bahwa Research and Development adalah metode penelitian yang digunakan untuk menghasilkan produk tertentu, dan selanjutnya menguji keefektifan produk tersebut. Sedangkan Borg dan Gall menyatakan bahwa " $R \& D$ is a process used to develop and validate educational products." Yakni, untuk meneliti dan menilai untuk mengembangkan bahan ajar ini, selanjutnya perlu memberikan rekomendasi perbaikan bahan ajar yang lebih berkualitas. Penelitian ini bertujuan untuk mengevaluasi kualitas bahan ajar bahasa Madura dari aspek kelayakan isi, dan kebahasaan. Menurut Ruseffensi (1998) penelitian evaluasi adalah penelitian yang bertujuan untuk membantu mengambil keputusan mengenai lebih baiknya sesuatu untuk dilaksanakan, dilihat dari sudut efektivitas, biayanya, dan lain-lain. Hasil penelitian evaluasi selain untuk mengetahui efektivitas dari suatu produk (bahan ajar bahasa Madura) juga menghasilkan rekomendasi perbaikan dari bahan ajar tersebut.Menurut Faisal dan Waseso (1982) bahwa seringkali evaluasi mengemukakan rekomendasi ke arah tindakan praktis perbaikan suatu produk.

Penelitian ini ingin mengetahui secara khusus mengenai bahan ajar bahasa Madura dari segi isi, bahasa, dan penyajiannya dengan metode deskriptif dan menggunakan teknik survey. Dengan metode ini peneliti dapat menggambarkan atau mendeskripsikan kedalaman bahan ajar tersebut, sehingga diperoleh gambaran yang sebenarnya sebagai bahan ajar bahasa Madura tingkat Sekolah Menengah Atas (SMA). Dengan demikian dapat diberikan masukan untuk memperbaikinya atau menyempurnakannya.

Adapun produk yang dikembangkan dalam penelitian ini adalah pengembangan bahan ajar mata pelajaran bahasa Madura tingkat Sekolah Menengah Atas (SMA). Borg dan Gall menjelaskan bahwa produk pendidikan meliputi dua jenis, yakni berupa objek-objek material, serta bangunan prosedur dan proses. Wujudnya dapat berupa tujuan belajar, metode, kurikulum, dan evaluasi, baik perangkat keras maupun lunak, baik cara maupun prosedurnya.

Prosedur penelitian ini menerapkan konsep Borg dan Gall, langkah-langkahnya meliputi: research and information, planning, develop preliminary, preliminary form 
of product, Main Product Revision, Main field testing, Operational product revision, Operational field testing, Final product revision, dan Disseminaton and implementation.

Skala yang digunakan untuk deskripsi kuantitaif adalah skala Likert. Lembar evaluasi ahli materi, guru, dan siswa menggunakan rentangan sangat baik, baik, cukup baik, kurang baik, dan sangat kurang baik. Sedangkan lembar angket siswa dan guru menggunakan skala sikap dengan rentangan sangat setuju, setuju, netral, tidak setuju, dan sangat tidak setuju. Penilaian sikap digunakan untuk mengukur sikap seseorang terhadap objek tertentu (positif, netral, dan negatif).

Adapun sampel bahan ajar yang digunakan sebagai objek penelitian ini adalah bahan ajar bahasa Madura tingkat Sekolah Menengah Atas (SMA). Sedangkan subyeknya adalah 1) siswa, dan 2) pakar/ahli materi bahasa Madura. Analisis data penelitian ini menggunakan deskriptif kuantitatif dan reduksi data. Yakni telaah Silabus/RPP dan bahan ajar yang digunakan, lembar angket siswa dan guru, lembar validitas untuk uji ahli, guru, dan lembar evaluasi untuk siswa.

Berikut ini analisis dokumen yang dilakukan peneliti.

1. Analisis RPP dan Bahan Ajar yang digunakan, analisis data yang dilakukan adalah dengan mereduksi data (data ditulis dalam bentuk uraian kemudian direduksi, dirangkum, dipilih hal-hal pokok, difokuskan kepada hal-hal penting) dan display data (data dimasukkan ke dalam matrik dan dianalisis).

2. Analisis Lembar Angket Siswa dan Guru, langkah-langkahnya adalah: a. Mengubah skor dari setiap butir pertanyaan, berdasarkan konsep Nurgiantoro.

b. Menjumlahkan skor dari setiap butir pertanyaan.

c. Menghitung skor total rata-rata dari setiap komponen.

d. Mengubah skor rata-rata menjadi nilai dengan kategori, konversi data kuantitatif menjadi data kualitatif tersebut menggunakan teori Sukardjo.

Jenis penelitian ini termasuk penelitian pengembangan. Yakni, untuk meneliti dan menilai untuk mengembangkan bahan ajar selanjutnya perlu memberikan rekomendasi perbaikan bahan ajar yang lebih berkualitas. Penelitian ini bertujuan untuk mengevaluasi kualitas bahan ajar bahasa Madura dari aspek kelayakan isi, dan kebahasaan. Menurut Ruseffensi (1998) penelitian evaluasi adalah penelitian yang bertujuan untuk membantu mengambil keputusan mengenai lebih baiknya sesuatu untuk dilaksanakan, dilihat dari sudut efektivitas, biayanya, dan lain-lain. Hasil penelitian evaluasi selain untuk mengetahui efektivitas dari suatu produk (bahan ajar bahasa Madura) juga menghasilkan rekomendasi perbaikan dari bahan ajar tersebut.Menurut Faisal dan Waseso (1982) bahwa seringkali penelitian evaluasi mengemukakan rekomendasi ke arah tindakan praktis perbaikan suatu produk.

Penelitian ini ingin mengetahui secara khusus mengenai bahan ajar bahasa Madura dari segi isi, bahasa, dan penyajiannya dengan metode deskriptif dan menggunakan teknik survey. Dengan metode ini peneliti dapat menggambarkan atau mendeskripsikan 
kedalaman bahan ajar tersebut, sehingga diperoleh gambaran yang sebenarnya sebagai bahan ajar bahasa Madura tingkat Sekolah Menengah Atas (SMA). Dengan demikian dapat diberikan masukan untuk memperbaikinya atau menyempurnakannya.

Adapun sampel bahan ajar yang digunakan sebagai objek penelitian ini adalah bahan ajar bahasa Madura tingkat Sekolah Menengah Atas (SMA). Sedangkan subyeknya adalah 1) siswa, dan 2) pakar/ahli materi bahasa Madura. Sedangkan instrumen penelitian ini terdiri dari: 1) kelayakan isi bahan ajar bahasa Madura, 2) kelayaan penyajian materi bahan ajar bahasa Madura, dan 3) kelayakan bahasa bahan ajar bahasa selain itu, penelitian ini juga menggunakan kuesioner, yang terdiri: guru mata pelajaran, siswa, dan pakar/ahli materi. Adapun rinciannya adalah (1) kuesioner untuk siswa meliputi: kelengkapan bahan ajar, penelaahan materi (bahasa, penyajian, dan materi), (2) kuesioner pakar 1 (ahli pembelajaran) dengan menggunakan kuesioner evaluasi mata pelajaran bahasa Madura, dan (3) kuesioner pakar 2 (ahli bahasa Madura) tentang validasi materi bahan ajar untuk semua bahan ajar yang ada.

Data tentang kualitas bahan ajar bahasa Madura dikumpulkan melalui kajian dokumen pendukung (dokumen Silabus bahasa Madura), sedangkan observasi, kuesioner bertujuan untuk memperoleh pendapat (validasi) terhadap bahan ajar bahasa Madura. Kuesioner diberikan kepada siswa, dan pakar (1 dan 2). Kemudian setiap data akan dianalisis berdasarkan skala Likert. Dengan demikian, teknik pengumpulan data dalam penelitian ini menggunakan analisis data deskriptif kuantitatif. Masukan saran serta kritik perbaikan pada angket instrumen validasi digunakan untuk menganalisis data yang diperoleh dalam bentuk analisis presentase. Data yang telah dikumpulkan pada lembar validasi angket uji coba terlebih dahulu diubah ke dalam data kuantitatif disesuaikan dengan bobot skor. Pengubahan dilakukan dengan rumus sebagai berikut (Arikunto, 2007).

$$
P=\frac{\sum x}{\sum x i} x 100 \%
$$

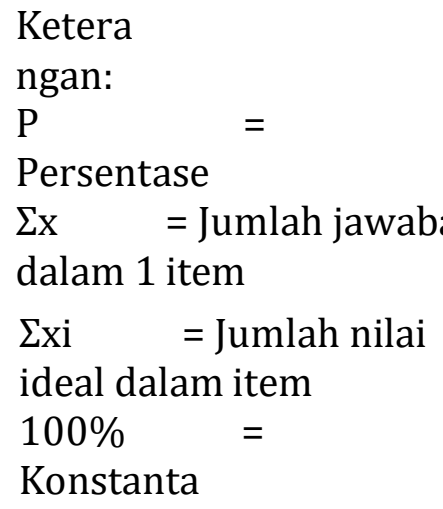

Adapun kriteria kevalidan data angket penilaian validator dapat ditinjau dari hasil persentase kriteria dalam Tabel 1.

Tabel 1. Kriteria Kevalidan Data Angket Penilaian Validator

\begin{tabular}{|c|c|}
\hline Skala Nilai (\%) & Tingkat Validitas \\
\hline $85,01-100,00$ & $\begin{array}{c}\text { Sangat valid, dapat } \\
\text { digunakan tetapi } \\
\text { perlu revisi kecil }\end{array}$ \\
\hline $70,01-85,00$ & $\begin{array}{c}\text { Valid, dapat } \\
\text { digunakan tetapi } \\
\text { perlu revisi kecil }\end{array}$ \\
\hline $50,01-70,00$ & $\begin{array}{c}\text { Kurang valid, dapat } \\
\text { digunakan tetapi } \\
\text { perlu revisi besar }\end{array}$ \\
\hline $01,00-50,00$ & $\begin{array}{c}\text { Tidak valid, tidak } \\
\text { boleh dipergunakan }\end{array}$ \\
\hline
\end{tabular}

(Sumber: Akbar, 2013) 


\section{HASIL DAN PEMBAHASAN}

Secara garis besar hasil penelitian ini meliputi dua bagian, yakni mengkaji kelengkapan dokumen (Kurikulum, Silabus, dan RPP) mata pelajaran bahasa Madura dan hasil persepsi para guru, para pakar (ahli) terhadap kualitas materi, kualitas kelayakan penyajian, dan keterbacaan bahan ajar yang kemudian dilakukan analisis deskriptif terhadap bahan ajar mata pelajaran bahasa Madura tingkat SMA.

Pada bagian ini, penulis akan menyampaikan data-data hasil penelitian lapangan tentang evaluasi bahan ajar mata pelajaran bahasa Madura tingkat SMA. Hal ini dilakukan untuk mengetahui tentang kualitas materi, kualitas kelayakan penyajian, dan keterbacaan bahan ajar yang kemudian dilakukan analisis deskriptif terhadap bahan ajar mata pelajaran bahasa Madura tingkat SMA. Adapun urutan kegiatan penelitian yang telah dilakukan peneliti adalah sebagai berikut:

1. Melakukan pemeriksaan kelengkapan dokumen kajian terhadap kurikulum bahasa Madura (peta kompetensi) dan keterkaitannya dengan bahan ajar mata pelajaran bahasa Madura.

2. Melakukan kajian masing-masing kompetensi pada jenjang SMA tentang materi pokok, dan model pembelajarannya.

3. Mengkaji kesesuaian dan kemutakhiran isi pokok bahasan.

4. Mengkaji hasil telaah bahan ajar secara keseluruhan untuk jenjang SMA.

5. Menganalisis persepsi guru dan siswa terhadap kualitas, penyajian, dan keterbacaan bahan ajar bahasa Madura.

6. Melihat evaluasi hasil pembelajaran dalam bahan ajar bahasa Madura.

7. Melihat keseluruhan daftar pustaka yang dicantumkan.

Tabel 2. Urutan Kegiatan Penilaian Bahan Ajar Bahasa Madura

\begin{tabular}{|c|c|c|}
\hline No. & Kegiatan & Hasil \\
\hline 1. & $\begin{array}{l}\text { Melakukan } \\
\text { pemeriksaan } \\
\text { kelengkapan } \\
\text { dokumen kajian } \\
\text { terhadap } \\
\text { kurikulum } \\
\text { bahasa Madura } \\
\text { (peta } \\
\text { kompetensi) dan } \\
\text { keterkaitannya } \\
\text { dengan bahan } \\
\text { ajar mata } \\
\text { pelajaran bahasa } \\
\text { Madura. }\end{array}$ & $\begin{array}{l}\text { Secara } \\
\text { keseluruhan } \\
\text { sudah cukup } \\
\text { memadai. } \\
\text { Untuk } \\
\text { beberapa } \\
\text { materi perlu } \\
\text { diperjelas lagi } \\
\text { dengan } \\
\text { contoh-contoh } \\
\text { yang terbaru. }\end{array}$ \\
\hline 2. & $\begin{array}{l}\text { Melakukan kajian } \\
\text { masing-masing } \\
\text { kompetensi pada } \\
\text { jenjang SMA } \\
\text { tentang materi } \\
\text { pokok, dan model } \\
\text { pembelajarannya. }\end{array}$ & $\begin{array}{l}\text { Peta } \\
\text { kompetensi } \\
\text { dalam } \\
\text { kurikulum } \\
\text { setiap jenjang } \\
\text { dalam bahan } \\
\text { ajar tidak ada, } \\
\text { namun } \\
\text { sajiannya telah } \\
\text { mencerminkan } \\
\text { kaidah-kaidah } \\
\text { penulisan yang } \\
\text { ditentukan. }\end{array}$ \\
\hline 3. & $\begin{array}{l}\text { Mengkaji } \\
\text { kesesuaian dan } \\
\text { kemutakhiran isi } \\
\text { pokok bahasan. }\end{array}$ & $\begin{array}{l}\text { Secara } \\
\text { keseluruhan } \\
\text { sudah cukup } \\
\text { memadai. } \\
\text { Untuk } \\
\text { beberapa } \\
\text { materi perlu } \\
\text { diperjelas }\end{array}$ \\
\hline
\end{tabular}




\begin{tabular}{|l|l|l|}
\hline 4. & $\begin{array}{l}\text { Mengkaji hasil } \\
\text { telaah bahan ajar } \\
\text { secara } \\
\text { keseluruhan } \\
\text { untuk jenjang } \\
\text { SMA. }\end{array}$ & $\begin{array}{l}\text { Pada } \\
\text { umumnya } \\
\text { sudah sesuai } \\
\text { dengan materi } \\
\text { pokok } \\
\text { berdasarkan } \\
\text { kurikulum. }\end{array}$ \\
\hline 5. & $\begin{array}{l}\text { Menganalisis } \\
\text { persepsi guru } \\
\text { dan siswa } \\
\text { terhadap } \\
\text { kualitas, } \\
\text { penyajian, dan } \\
\text { keterbacaan } \\
\text { bahan ajar } \\
\text { bahasa Madura. }\end{array}$ & $\begin{array}{l}\text { Persepsi dari } \\
\text { guru dan siswa } \\
\text { sebagian besar } \\
\text { menilai positif } \\
\text { dan lebih baik, } \\
\text { namun ada } \\
\text { beberapa } \\
\text { bahan ajar } \\
\text { yang perlu } \\
\text { direvisi. }\end{array}$ \\
\hline 6. & $\begin{array}{l}\text { Bentuk } \\
\text { evaluasi hasil } \\
\text { belajar sudah } \\
\text { memadai, } \\
\text { hasil } \\
\text { pembelajaran } \\
\text { dalam bahan ajar } \\
\text { bahasa Madura. } \\
\text { ditunjang } \\
\text { dengan media } \\
\text { non cetak yang } \\
\text { lain. }\end{array}$ \\
\hline $\begin{array}{l}\text { yangaras pustaka } \\
\text { dicantumkan. }\end{array}$ & $\begin{array}{l}\text { Daftar pustaka } \\
\text { pada bahan } \\
\text { ajar sudah } \\
\text { memadai, } \\
\text { tetapi } \\
\text { diperlukan } \\
\text { bahan pustaka } \\
\text { terbaru yang } \\
\text { sesuai agar } \\
\text { materi dalam } \\
\text { bahan } \\
\text { teks tidak } \\
\text { tertinggal. }\end{array}$ \\
\hline
\end{tabular}

Berdasarkan tahapan di atas, pembahasan tulisan ini akan mendeskripsikan tentang hal-hal berdasarkan data temuan dalam penelitian. Yakni meliputi data respon siswa, dan hasil validasi ahli. Berikut ini akan dirincikan setiap data yang didapatkan oleh peneliti.

\section{a. Respon Siswa}

Adapun respon siswa yang dibahas adalah tentang tampilan bahan ajar, penyajian materi bahan ajar, dan manfaat bahan ajar. Berdasarkan data kuesioner yang diberikan kepada siswa, hasil penelitian menunjukkan bahwa secara umum nilai tampilan bahan ajar bahasa Madura dalam kategori kurang valid, dapat digunakan tetapi perlu revisi besar, yakni sebesar 69,01 sesuai dengan prosentase kriteria. Adapun rincian dari masing-masing item yang diangketkan tentang tampilan bahan ajar ini adalah sebagai berikut.

Tabel 3. Nilai Respon Siswa tentang Tampilan Bahan Ajar

\begin{tabular}{|l|l|c|}
\hline No. & \multicolumn{1}{|c|}{ Pernyataan } & Nilai \\
\hline 1. & $\begin{array}{l}\text { Teks atau tulisan } \\
\text { mudah dibaca }\end{array}$ & 13,75 \\
\hline 2. & $\begin{array}{l}\text { Gambar ditampilkan } \\
\text { jelas/tidak buram }\end{array}$ & 10,16 \\
\hline 3. & $\begin{array}{l}\text { Gambar ditampilkan } \\
\text { cukup (tidak terlalu } \\
\text { banyak dan tidak } \\
\text { terlalu sedikit) }\end{array}$ & 11,20 \\
\hline 4. & $\begin{array}{l}\text { Gambar disertai } \\
\text { keterangan }\end{array}$ & 11,41 \\
\hline 5. & $\begin{array}{l}\text { Gambar ditampilkan } \\
\text { secara menarik }\end{array}$ & 10,36 \\
\hline 6. & Gambar sesuai materi & 12,14 \\
\hline & Total Nilai & $\mathbf{6 9 , 0 1}$ \\
\hline
\end{tabular}

Berdasarkan data kuesioner yang diberikan kepada siswa, hasil penelitian menunjukkan bahwa secara umum nilai penyajian materi bahan ajar bahasa 
Madura dalam kategori valid, dapat digunakan tetapi perlu revisi kecil yakni sebesar 72,74 sesuai dengan prosentase kriteria. Adapun rincian dari masingmasing item yang diangketkan tentang penyajian materi bahan ajar ini adalah sebagai berikut.

Tabel 4. Nilai Respon Siswa tentang Penyajian Materi Bahan Ajar

\begin{tabular}{|l|l|c|}
\hline No. & \multicolumn{1}{|c|}{ Pernyataan } & Nilai \\
\hline 1. & $\begin{array}{l}\text { Bahan ajar ini } \\
\text { menjelaskan suatu } \\
\text { konsep menggunakan } \\
\text { ilustrasi masalah yang } \\
\text { berkaitan dengan } \\
\text { kehidupan sehari-hari. }\end{array}$ & 6,08 \\
\hline 2. & $\begin{array}{l}\text { Bahan ajar ini } \\
\text { menggunakan contoh- } \\
\text { contoh soal yang } \\
\text { berkaitan dengan } \\
\text { masalah kehidupan } \\
\text { sehari-hari. }\end{array}$ & \\
\hline 3. & $\begin{array}{l}\text { Jika dalam proses } \\
\text { pembelajaran } \\
\text { menggunakan bahan } \\
\text { ajar ini saya } \\
\text { menghadapi masalah, } \\
\text { maka saya berani } \\
\text { bertanya dan } \\
\text { mengemukakan } \\
\text { masalah yang saya } \\
\text { hadapi kepada guru. }\end{array}$ & 5,89 \\
\hline 4. & $\begin{array}{l}\text { Penyajian materi } \\
\text { dalam bahan ajar ini } \\
\text { mendorong saya } \\
\text { untuk berdiskusi } \\
\text { dengan teman-teman } \\
\text { yang lain. }\end{array}$ & 5,84 \\
\hline 5. & $\begin{array}{l}\text { Penyajian materi } \\
\text { dalam bahan ajar ini } \\
\text { berkaitan dengan } \\
\text { materi bahasa } \\
\text { Madura yang lain } \\
\text { atau dengan mata } \\
\text { pelajaran yang lain }\end{array}$ & 5,65 \\
\hline
\end{tabular}

\begin{tabular}{|l|l|r|}
\hline & $\begin{array}{l}\text { dalam pemecahan } \\
\text { masalah dan } \\
\text { penerapannya. }\end{array}$ & \\
\hline 6. & $\begin{array}{l}\text { Saya dapat memahami } \\
\text { materi dengan mudah. }\end{array}$ & 5,53 \\
\hline 7. & $\begin{array}{l}\text { Materi yang disajikan } \\
\text { dalam bahan ajar } \\
\text { sudah runtut. }\end{array}$ & 6,01 \\
\hline 8. & $\begin{array}{l}\text { Saya dapat mengikuti } \\
\text { kegiatan belajar tahap } \\
\text { demi tahap dengan } \\
\text { mudah. }\end{array}$ & 5,55 \\
\hline 9. & $\begin{array}{l}\text { Saya dapat dengan } \\
\text { mudah memahami } \\
\text { kalimat yang } \\
\text { digunakan dalam } \\
\text { bahan ajar ini. }\end{array}$ & 4,95 \\
\hline 10. & $\begin{array}{l}\text { Tidak ada kalimat } \\
\text { yang menimbulkan } \\
\text { makna ganda dalam } \\
\text { bahan ajar ini. }\end{array}$ & 4,93 \\
\hline 11. & $\begin{array}{l}\text { Saya dapat memahami } \\
\text { lambang atau symbol } \\
\text { yang digunakan pada } \\
\text { bahan ajar ini. }\end{array}$ & $\begin{array}{l}\text { Saya dapat memahami } \\
\text { istilah-istilah yang } \\
\text { digunakan dalam } \\
\text { bahan ajarini. }\end{array}$ \\
\hline 13. & $\begin{array}{l}\text { Contoh soal yang } \\
\text { digunakan dalam } \\
\text { bahan ajar ini sudah } \\
\text { sesuai dengan materi. }\end{array}$ & 6,20 \\
\hline 12. & Total Nilai \\
\hline Serdasarkan & $\mathbf{7 2 , 7 4}$ \\
\hline
\end{tabular}

Berdasarkan data kuesioner yang diberikan kepada siswa, hasil penelitian menunjukkan bahwa secara umum nilai manfaat bahan ajar bahasa Madura masing item yang diangketkan tentang manfaat bahan ajar ini adalah sebagai berikut.

Tabel 5. Nilai Respon Siswa tentang Manfaat Bahan Ajar

\begin{tabular}{|l|c|c|}
\hline No. & Pernyataan & Nilai \\
\hline 1. & $\begin{array}{l}\text { Saya dapat memahami } \\
\text { materi bahasa Madura }\end{array}$ & \\
\hline
\end{tabular}




\begin{tabular}{|l|l|l|}
\hline & $\begin{array}{l}\text { menggunakan bahan } \\
\text { ajar ini dengan mudah. }\end{array}$ & 12,29 \\
\hline 2. & $\begin{array}{l}\text { Saya merasa lebih } \\
\text { mudah belajar dengan } \\
\text { menggunakan bahan } \\
\text { ajar ini. }\end{array}$ & 12,08 \\
\hline 3. & $\begin{array}{l}\text { Saya sangat tertarik } \\
\text { menggunakan bahan } \\
\text { ajar ini. }\end{array}$ & 11,46 \\
\hline 4. & $\begin{array}{l}\text { Dengan menggunakan } \\
\text { bahan ajar ini saya } \\
\text { lebih tertarik dalam } \\
\text { belajar bahasa Madura. }\end{array}$ & 11,15 \\
\hline 5. & $\begin{array}{l}\text { Dengan adanya } \\
\text { ilustrasi di seti apawal } \\
\text { materi dapat } \\
\text { memberikan motivasi } \\
\text { untuk mempelajari } \\
\text { materi bahasa Madura. }\end{array}$ & \\
12. & $\begin{array}{l}\text { Saya lebih rajin belajar } \\
\text { dengan menggunakan } \\
\text { bahan ajar ini. }\end{array}$ & 10,89 \\
\hline
\end{tabular}

Berdasarkan data-data di atas berdasarkan respon siswa tentang bahan ajar bahasa Madura yang dipergunakan di sekolah adalah dalam kategori valid, dapat digunakan tetapi perlu revisi kecil, yakni 70,64 sesuai dengan prosentase kriteria. Adapun dalam kategori valid, dapat digunakan tetapi perlu revisi kecil, yakni sebesar 70,16 sesuai dengan prosentase kriteria. Adapun rincian dari masing- masing item yang diangketkan tentang bahan ajar ini adalah sebagai berikut.

Tabel 6. Nilai Rata-rata Respon Siswa tentang Bahan Ajar

\begin{tabular}{|l|l|c|}
\hline No. & \multicolumn{1}{|c|}{ Pernyataan } & Nilai \\
\hline 1. & $\begin{array}{l}\text { Respon Siswa tentang } \\
\text { Tampilan Bahan Ajar }\end{array}$ & $\mathbf{6 9 , 0 1}$ \\
\hline 2. & $\begin{array}{l}\text { Respon Siswa tentang } \\
\text { Penyajian Materi } \\
\text { Bahan Ajar }\end{array}$ & $\mathbf{7 2 , 7 4}$ \\
\hline 3. & $\begin{array}{l}\text { Respon Siswa tentang } \\
\text { Manfaat Bahan Ajar }\end{array}$ & $\mathbf{7 0 , 1 6}$ \\
\hline & Nilai Rata-rata & $\mathbf{7 0 , 6 4}$ \\
\hline
\end{tabular}

\section{Validasi Ahli}

Adapun validasi ahli yang dibahas adalah tentang tampilan bahan ajar, penyajian materi bahan ajar, dan manfaat bahan ajar.

Berdasarkan instrumen validasi yang diberikan kepada ahli materi, hasil penelitian menunjukkan bahwa secara umum nilai kelayakan isi bahan ajar bahasa Madura dalam kategori kurang valid dan dapat digunakan tetapi perlu revisi yakni sebesar $\mathbf{6 6 , 2 7}$ sesuai dengan kriteria tingkat validitas.Adapun rincian dari masing-masing item yang diangketkan tentang kelayakan isi bahan ajar ini adalah sebagai berikut.

Tabel 7. Data Validasi Tim Ahli Materi tentang Kelayakan Isi

\begin{tabular}{|c|l|r|}
\hline $\begin{array}{c}\text { No } \\
\cdot\end{array}$ & \multicolumn{1}{|c|}{ Pernyataan } & Nilai \\
\hline 1. & Kelengkapan materi & 3,77 \\
\hline 2. & Keluasan materi. & 3,37 \\
\hline 3. & Kedalaman materi & 3,57 \\
\hline 4. & $\begin{array}{l}\text { Keakuratan konsep dan } \\
\text { definisi. }\end{array}$ & 2,98 \\
\hline 5. & Keakuratan prinsip. & 2,78 \\
\hline 6. & $\begin{array}{l}\text { Keakuratan fakta dan } \\
\text { data. }\end{array}$ & 3,17 \\
\hline 7. & Keakuratan contoh & 2,78 \\
\hline 8. & Keakuratan soal & 3,17 \\
\hline 9. & $\begin{array}{l}\text { Keakuratangambar,diag } \\
\text { ram dan ilustrasi. }\end{array}$ & 2,98 \\
\hline 10. & $\begin{array}{l}\text { Keakuratannotasi,simbo } \\
\text { l,dan ikon. }\end{array}$ & 2,98 \\
\hline 11. & Keakuratan acuan & 3,17 \\
\hline & pustaka. & \\
\hline 12. & Penalaran(reasoning) & 3,17 \\
\hline 13. & Keterkaitan & 3,37 \\
\hline 14. & $\begin{array}{l}\text { Komunikasi(writeandtal } \\
\text { k) }\end{array}$ & 3,37 \\
\hline 15. & Penerapan & 3,17 \\
\hline 16. & Kemenarikan materi & 2,98 \\
\hline 17. & $\begin{array}{l}\text { Mendorong untuk } \\
\text { mencari informasi lebih } \\
\text { jauh }\end{array}$ & 2,78 \\
\hline & & \\
\hline
\end{tabular}




\begin{tabular}{|c|c|c|}
\hline 18. & $\begin{array}{l}\text { Kesesuaian, materi } \\
\text { dengan perkembangan } \\
\text { ilmu. }\end{array}$ & 3,37 \\
\hline 19. & $\begin{array}{l}\text { Gambar, diagram, dan } \\
\text { ilustrasi aktual. }\end{array}$ & 2,98 \\
\hline 20. & $\begin{array}{l}\text { Menggunakan contoh } \\
\text { kasus di dalam dan luar } \\
\text { Indonesia }\end{array}$ & 3,17 \\
\hline 21. & Kemutakhiran pustaka. & 3,17 \\
\hline & Total Nilai & $\begin{array}{c}66,2 \\
7\end{array}$ \\
\hline
\end{tabular}

Berdasarkan instrumen validasi yang diberikan kepada ahli materi, hasil penelitian menunjukkan bahwa secara umum nilai kelayakan penyajian bahan ajar bahasa Madura dalam kategori kurang valid dan dapat digunakan tetapi perlu revisi, yakni sebesar $\mathbf{6 5 , 7 7}$ sesuai dengan kriteria tingkat validitas. Adapun rincian dari masing-masing item yang diangketkan tentang kelayakan penyajian bahan ajar ini adalah sebagai berikut.

Tabel 8. Data Validasi Tim Ahli Materi tentang Kelayakan Penyajian

\begin{tabular}{|l|c|c|}
\hline No. & Pernyataan & Nilai \\
\hline 1. & $\begin{array}{l}\text { Konsistensi sajian } \\
\text { sistematika } \\
\text { dalamkegiatan belajar. }\end{array}$ & 5,36 \\
\hline 2. & Keruntutan penyajian. & 4,46 \\
\hline 3. & $\begin{array}{c}\text { Contoh-contoh soal } \\
\text { dalam setiap kegiatan } \\
\text { belajar. }\end{array}$ & 4,46 \\
\hline 4. & $\begin{array}{c}\text { Soal latihan pada } \\
\text { setiap akhir kegiatan }\end{array}$ & 4,46 \\
\hline & belajar. & \\
\hline 5. & $\begin{array}{c}\text { Kunci jawaban soal } \\
\text { latihan. }\end{array}$ & 5,06 \\
\hline 6. & $\begin{array}{c}\text { Umpan balik soal } \\
\text { latihan. }\end{array}$ & 4,76 \\
\hline 7. & Pengantar. & 5,36 \\
\hline 8. & Glosarium. & 4,46 \\
\hline 9. & Daftar Pustaka. & 4,76 \\
\hline 10. & Rangkuman & 4,17 \\
\hline 11. & $\begin{array}{c}\text { Keterlibatan peserta } \\
\text { didik. }\end{array}$ & 4,76 \\
\hline 12. & Bagian pendahuluan & 4,46 \\
\hline
\end{tabular}

\begin{tabular}{|c|c|l|}
\hline 13. & Bagian Isi & 4,46 \\
\hline 14. & Bagian Penyudah & 4,76 \\
\hline & Total Nilai & 65,77 \\
\hline
\end{tabular}

Berdasarkan instrumen validasi yang diberikan kepada ahli materi, hasil penelitian menunjukkan bahwa secara umum nilai kelayakan bahasa bahan ajar bahasa Madura dalam kategori kurang valid dan dapat digunakan tetapi perlu revisi yakni sebesar $\mathbf{6 8 , 5 9}$ sesuai dengan kriteria tingkat validitas. Adapun rincian dari masing-masing item yang diangketkan tentang kelayakan penyajian bahan ajar ini adalah sebagai berikut.

Tabel 9. Data Validasi Tim Ahli Materi tentang Kelayakan Bahasa

\begin{tabular}{|l|l|r|}
\hline No. & \multicolumn{1}{|c|}{ Pernyataan } & Nilai \\
\hline 1. & $\begin{array}{l}\text { Ketepatan struktur } \\
\text { kalimat. }\end{array}$ & 5,77 \\
\hline 2. & Keefektifan kalimat. & 5,13 \\
\hline 3. & Kebakuan istilah. & 5,77 \\
\hline 4. & Keterbacaan pesan & 4,49 \\
\hline 5. & $\begin{array}{l}\text { Ketepatan } \\
\text { penggunaan kaidah } \\
\text { bahasa. }\end{array}$ & 5,45 \\
\hline 6. & $\begin{array}{l}\text { Kemampuan } \\
\text { memotivasi pesan } \\
\text { atau informasi. }\end{array}$ & $\begin{array}{l}\text { Kemampuan } \\
\text { mendorong } \\
\text { berpikir kritis. }\end{array}$ \\
\hline 8. & $\begin{array}{l}\text { Kesesuaian } \\
\text { perkembangan } \\
\text { intelektual } \\
\text { peserta didik. }\end{array}$ & 5,49 \\
\hline 9. & $\begin{array}{l}\text { Kesesuian dengan } \\
\text { tingkat } \\
\text { perkembangan } \\
\text { emosional } \\
\text { peserta } \\
\text { didik. }\end{array}$ & 5,45 \\
\hline 10. & $\begin{array}{l}\text { Keruntutan dan } \\
\text { keterpaduan } \\
\text { antar kegiatan }\end{array}$ & 5,45 \\
\hline
\end{tabular}




\begin{tabular}{|c|l|l|}
\hline & belajar & \\
\hline 11. & $\begin{array}{l}\text { Keruntutan dan } \\
\text { keterpaduan } \\
\text { antar paragraf }\end{array}$ & 5,77 \\
\hline 12. & $\begin{array}{l}\text { Konsistensi } \\
\text { penggunaan } \\
\text { istilah. }\end{array}$ & 5,13 \\
\hline 13. & $\begin{array}{l}\text { Konsistensi } \\
\text { penggunaan } \\
\text { simbol atau ikon. }\end{array}$ & 5,77 \\
\hline & $\begin{array}{l}\text { Total Nilai } \\
68,59\end{array}$ \\
\hline
\end{tabular}

Berdasarkan data-data di atas, hasil validasi ahli materi tentang bahan ajar bahasa Madura yang dipergunakan di sekolah adalah dalam kategori kurang valid dan dapat digunakan tetapi perlu revisi, yakni 66,88 sesuai dengan kriteria tingkat validitas. Adapun rincian dari masingmasing item yang diangketkan tentang bahan ajar ini adalah sebagai berikut.

Tabel 10. Nilai Rata-rata Hasil Validasi tentang Bahan Ajar

\begin{tabular}{|l|l|c|}
\hline No. & \multicolumn{1}{|c|}{ Pernyataan } & Nilai \\
\hline 1. & $\begin{array}{l}\text { Nilai Validasi tentang } \\
\text { Kelayakan Isi }\end{array}$ & 66,27 \\
\hline 2. & $\begin{array}{l}\text { Nilai Validasi tentang } \\
\text { Kelayakan Penyajian }\end{array}$ & 65,77 \\
\hline 3. & $\begin{array}{l}\text { Nilai Validasi tentang } \\
\text { Kelayakan Bahasa }\end{array}$ & 68,59 \\
\hline & Nilai Rata-rata & $\mathbf{6 6 , 8 8}$ \\
\hline
\end{tabular}

\section{SIMPULAN}

Berdasarkan pembahasan di atas, peneliti dapat menyimpulkan bahwa (1) berdasarkan respon siswa, bahan ajar bahasa Madura yang digunakan di Sekolah Menengah Atas (SMA) mendapatkan nilai 70,64 dan dalam kategori valid dan dapat digunakan tetapi perlu revisi kecil. Sedangkan berdasarkan hasil validasi ahli, bahan ajar bahasa Madura yang digunakan di Sekolah Menengah Atas (SMA) mendapatkan nilai 66,88 dan dalam kategori kurang valid dan dapat digunakan tetapi perlu revisi. Adapun saran yang dapat diberikan adalah hendaknya pihak-pihak yang terkait (guru, penulis, dan praktisi) lebih kontekstual dalam memberikan materi maupun contoh dalam bahan ajar teks sehingga mudah dipahami siswa serta disajikan dengan secara menarik.

\section{DAFTAR RUJUKAN}

Borg, R Walter dan Gall Meredith D. 1989. Educational Research An Introduction. Longman: Fifth Edition.

Greene, Harry A \& Walter T Petty. 1971. Developing Language Skills in The Elementary Schools. Boston: Allyn and Bacon, Inc.

Hanafiah, Nanang, dan Cucu Suhana. 2009. Konsep Strategi

Pembelajaran. Bandung: PT Refika Aditama.

Muslich, Masnur. 2010. Text Book Writing: Dasar-Dasar Pemahaman, Penulisan, dan Pemakaian Buku Teks: Jogjakarta: Ar-ruzz Media.

Nurgiantoro, Burhan. 2010. Penilaian Pembelajaran Bahasa: Berbasis Kompetensi. Yogyakarta: BPFE.

Sitepu, B.P., 2012. Penulisan Buku Teks Pelajaran. Bandung: PT Remaja Rosdakarya.

Sugiyono. 2009. Metode Penelitian 
Kuantitatif, Kualitatif dan R\&D. Universitas Madura.

Bandung: Alfabeta.

Umar, Jahja. 2011. Progress In

International Reading Literacy

Study (PIRLS). Executive

Summary.

Internation

al Benchmarks TIMMS \& PIRLS

Report International study

Center (IEA): Lynch School of

Education, Boston College

\section{Profil}

Singkat

M. Khoiri lahir di Banyuwangi pada tanggal 18 Maret 1983. Menempuh pendidikan S1 Program Studi Pendidikan Bahasa dan Sastra Indonesia di Universitas Madura Pamekasan, lulus pada tahun 2009. Selanjutnya, menempuh studi S2 Magister Pendidikan di Pasca Sarjana Universitas Islam Malang lulus pada tahun 2013. Berprofesi sebagai dosen Program Studi Pendidikan Bahasa dan Sastra Indonesia di Universitas Madura.

Kusyairi lahir di Pamekasan pada tanggal $16 \quad$ Mei 1981. Menempuh pendidikan S1 Program Studi Pendidikan Bahasa dan Sastra Indonesia di Universitas Madura Pamekasan, lulus pada tahun 2010. Selanjutnya, menempuh studi S2 Magister Pendidikan di Pasca Sarjana Universitas Islam Malang lulus pada tahun 2013. Berprofesi sebagai dosen Program Studi Pendidikan Bahasa dan Sastra Indonesia di 